\title{
Effect Thought Stopping (Ts)/Negative Thinking Stop To Thinking Process Drugs Abuse At Lembaga Pembinaan Khusus Anak Pekanbaru
}

\author{
Usraleli', Sri Mulyenti ${ }^{1}$ \\ Poltekkes Kemenkes Riau, Nursing Departemen ${ }^{1}$ \\ usraleli@pkr.ac.id
}

\section{Article Info}

Article history

Received date: 2019-10-31

Revised date: 2019-11-28

Accepted date: 2019-11-28

\begin{abstract}
One of the trends and issues of mental health is drug abuse. The results of the Substance Abuse and Menthal Health Services Administration survey said that children aged 12-17 years $9 \%$ used illegal substances and $18.8 \%$ sonsumed alcohol in a month (Videbeck, 2008). Thought stopping is done by severing threatening thoughts or obsessions by saying "STOP" when threatening thoughts and feelings emerge and replacing those thoughts with positive thoughts. The method used is discussion, question and answer and role play / independent practice. Objective: to identify the effectiveness of Assertiveness Training (AT)/Assertive Behavior in drug users. The results showed that the ability of fostered citizens to stop negative thoughts towards the thought process before was 4, 64 and after thought stopping has done, it increases two times. Thought stopping is effective in turning negative thoughts into positive thoughts. Thought stopping therapy is effective in changing negative thoughts into positive thoughts in fostered people who are undergoing rehabilitation at the Pekanbaru Children's Special Development Institute. It is hoped that LKPA can improve cross-program and cross-sectoral cooperation including the health, social and employment agencies so that the skills acquired during coaching remain sustainable
\end{abstract}

Keywords

Effect, Thought Stopping, thinking process drugs abuse

\section{Abstrak}

Salah satu trend dan issue kesehatan jiwa ini adalah penyalahgunaan NAPZA. Hasil survei Substance Abuse and Menthal Health Services Administration menyebutkan anak usia 12-17 tahun 9\% menggunakan zat terlarang dan 18,8\% mengkonsumsi alkohol dalam sebulan (Videbeck, 2008). Thought stopping dilakukan dengan cara memutuskan pikiran atau obsesi yang mengancam dengan mengatakan "STOP" ketika pikiran dan perasaan yang mengancam muncul dan menggantikan pikiran tersebut dengan pikiran positif. Metode yang digunakan adalah diskusi, tanya jawab dan role play/praktik mandiri. Tujuan : mengidentifikasi efektivitas Assertiveness Training (AT)/Perilaku Assertive pada penyalahguna NAPZA. Hasil penelitian menunjukkan bahwa kemampuan warga binaan menghentikan pikiran negatif terhadap proses pikir sebelum adalah 4, 64 dan sesudah dilakukan thought stopping meningkat dua kali lipat.Thought stopping efektif dalam mengubah pikiran negatif menjadi pikiran positif.Terapithought stopping efektif dalam mengubah pikiran negatif menjadi pikiran positif pada warga binaan yang sedang menjalani rehabilitasi di Lembaga Pembinaan Khusus Anak Pekanbaru. Diharapkkan pihak LKPA dapat meningkatkan kerja sama lintas program dan lintas sektoral antara lain dinas kesehatan, sosial dan ketenaga kerjaan agar keterampilan yang telah didapatkan saat pembinaan tetap berkesinambungan

Kata Kunci

Pengaruh, Thought Stopping , Proses pikir penyalahguna NAPZA 


\section{PENDAHULUAN}

Salah satu trend dan issue kesehatan jiwa ini adalah penyalahgunaan NAPZA di samping masalah kejiwaan yang timbul akibat terjadinya perubahan sosial seperti psikotik gelandangan, pemasungan, masalah anak jalanan dan masalah anak remaja. Pemakaian NAPZA menjadi style (gaya hidup orang sukses) dan mekanisme koping dalam mengatasi stres dan frustasi menghadapi kehidupan serba canggih dan cepat.

Menurut penelitian BNN, Pusdiklat UI dan berbagai universitas negeri terkemuka tahun 2005 prevalensi penyalahgunaan narkotika, psikotropika dan zat terlarang ialah 1,75\% dari jumlah penduduk di Indonesia, tahun 2008 naik menjadi 1,88\%, tahun 2011 menjadi $2,2 \%$ dan tahun 2012 naik kembali menjadi 2,8\% (setara dengan 5,8 juta penduduk). Faktanya pengguna NAPZA semakin banyak, bahkan ke aparat pemerintah dan penegak hukum ${ }^{1}$.

Hasil penelitian tahun 2008 jumlah penyalahgunaan NAPZA sebanyak 3,3 juta orang, tahun 2011 meningkat $3,8 \%$ dan tahun 2013 mencapai 4,2 juta orang $(2,2 \%)$ yang terdiri dari pengguna coba pakai, teratur pakai, dan pecandu. Kurun waktu empat tahun terakhir, telah terungkap 108.107 kasus kejahatan NAPZA dengan tersangka sebanyak 134.117 orang. Lima provinsi dengan kasus NAPZA tertinggi di Indonesia tahun 2012 adalah Jawa Timur 7.448 kasus, DKI Jakarta 5.426 kasus, Sumatera Utara 2.420 kasus, Jawa Barat 1.252 kasus dan Jawa Tengah 1.194 kasus. Di Riau jumlah kasus NAPZA adalah 650 dan termasuk provinsi urutan keempat kasus NAPZA yang terus meningkat dalam 3 tahun terakhir setelah Kalimantan Selatan, Sulawesi Utara, Aceh dan Lampung 2.

Masalah penyalahgunaan NAPZA memerlukan upaya penanggulangan secara komprehensif dengan kerja sama multidispliner, multisektor, dan peran serta masyarakat secara aktif yang dilaksanakan secara berkesinambungan, konsekuen, dan konsisten. Mengingat NAPZA merupakan substansi yang dapat mempengaruhi fungsi pikiran, perasaan dan perilaku individu yang memakainya maka dipandang sangat penting untuk memberikan terapi yang disebut thought stopping. Terapi ini dilakukan selama 45 menit setiap muncul pikiran negatif untuk kurun waktu 2 minggu 3.

Tujuan terapi thought stopping adalah membantu klien mengatasi kecemasan yang mengganggu, membantu klien mengatasi pikiran negative atau maladaptive yang sering muncul dan membantu klien mengatasi pikiran obsesif dan fobia. Teknik penghentian pikiran paling tepat digunakan ketika pikiran disfungsional pertama mulai terjadi.

\section{METODE}

Metode yang digunakan adalah diskusi, tanya jawab dan role play/praktik mandiri. Untuk memperlancar terapi ini diperlukan alat dan bahan berupa alat tulis, kertas, alarm dan alat perekam.

Desain penelitian Quasy Experiment dengan one group pre and post test intervention dengan melakukan latihan thought stopping mengubah pikiran negatif menjadi pikiran positif dengan cara mengevaluasi kemampuan warga binaan Lapas.Sebagai kelompok intervensi adalah warga binaan dengan kasus NAPZA yang menjalani masa rehabilitasi sebanyak 25 orang.Teknikpengambilansampelyaitutotal samplingsebanyak 25 orangwarga binaan. Pelaksanaanthought stopping dilakukan dalam tiga sesi, yaitu : Sesi 1 yaitu berlatih pemutusan pikiran dengan menggunakan alarm. Sesi 2 yaitu berlatih pemutusan pikiran dengan menggunakan tanda "STOP" dan sesi 3 adalah berlatih pemutusan pikiran secara otomatis (suara/berbisik).

Untuk sesi 1 responden dilatih mengidentifikasi beberapa pikiran negatif terutama pikiran seputar sugesti terhadap NAPZA (minimal 5 pikiran negatif, jika lebih dari 5 semakin baik) lalu melakukan terapi dengan menggunakan alarm. Peneliti mengarahkan pikiran tersebut adalah pikiran negatif yang mengganggu dan berulang kali terjadi bagi responden. Untuk sesi 2 responden memilih/menentukan 
pikiran yang paling mengganggu dan membuat cemas diantara beberapa pikiran negatif di sesi 1, anak binaan lapas dianjurkan rileks dengan cara menarik nafas dalam 3-4 kali, lalu memandang satu titik pada dinding atau menutup mata sambil mengosongkan pikiran, memikirkan kembali pikiran yang mengganggu yang telah dipilih, Pada saat terapis memperlihatkan tanda "STOP" sambil mengucapkan "STOP", responden mampu menghilangkan pikiran negatif tersebut dan kembali rileks selama 1 menit, responden diarahkan menyebutkan beberapa pikiran positif untuk menggantikan pikiran negatif. Untuk sesi 3 sama tahapannya seperti sesi 2 , hanya pada sesi 3 ini suara "STOP" diucapkan sendiri oleh responden dengan volume suara normal 1 kali dan dengan berbisik 1 kali, menghentikan pikiran negatif tersebut dan menyebutkan pikiran positif untuk menggantikan pikiran negatif.

\section{HASIL DAN PEMBAHASAN}

\section{Analisa Univariat}

Karakteritik warga binaan pemasyarakatan terdiri dari umur, agama, pendidikan, lama menyalahgunakan, alasan menyalahgunakan dan anggota keluarga yang juga penyalahguna selengkapnya dapat dilihat pada tabel berikut ini.

Tabel 1.

Distribusi Frekuensi Warga Binaan Berdasarkan Umur di LPKA Pekanbaru Tahun 2016 ( $n=25)$

\begin{tabular}{ccc}
\hline Umur (tahun) & $\begin{array}{c}\text { Frekuensi } \\
\text { (orang) }\end{array}$ & $\begin{array}{c}\text { Persentase } \\
(\%)\end{array}$ \\
\hline $24-28$ & 5 & 20 \\
\hline $25-33$ & 6 & 24 \\
\hline $34-38$ & 7 & 28 \\
\hline $39-43$ & 4 & 16 \\
\hline $44-48$ & 2 & 8 \\
\hline$\geq 49$ tahun & 1 & 4 \\
\hline Total & $\mathbf{2 5}$ & $\mathbf{1 0 0}$ \\
\hline
\end{tabular}

Berdasarkan tabel 5.1 di atas dapat dilihat bahwa mayoritas responden berada dalam kelompok umur 34-38 tahun sebanyak 7 orang (28\%).

Hasil penelitian ini sejalan dengan penelitian Sartika (2010), Windiarti (2013) dan Diamaluddin (2014) yang semua usianya $<30$ tahun. Penelitian Sartika (2010) dan Diamaluddin (2014) mengatakan rata-rata usia klien yang menjalani terapi relapse prevention training di DKI adalah 28,75 tahun ${ }^{4,5}$. Penelitian Windiarti (2013) tentang pengaruh terapi stop berfikir negatif terhadap ketergantungan narkoba di Panti Rehabilitasi NAPZA di Rumah Damai Gunung Pati Semarang yang mengatakan $56,7 \%$ penderita ketergantungan NAPZA dari kelompok umur 20-30 tahun ${ }^{6}$. Penelitian Rustyawati (2010) yang menyebutkan $72 \%$ umur korban penyalahguna narkoba yang menjalani terapi di Semarang adalah 21-30 tahun7. Peneliti menganalis bahwa rata-rata usia warga binaan 34-38 tahun menurut Erik Erikson adalah termasuk usia dewasa muda yaitu mulai dari 19-34 tahun. Usia ini ditandai denganindividu masih ingin menggabungkan identitas dirinya dengan kelompok, ingin diterima, diakui kelompok sebaya (Nurdin, 2011)8. Pada usia ini juga sering labil dalam menangani dan menerima pengaruh dari luar, sehingga lebih mudah terpengaruh dengan lingkungan atau orang di sekitarnya. Individu yang berusia muda (murid SD) akan lebih mudah menerima perubahan termasuk mengadopsi perilaku menyalahgunakan zat. Anak belum mampu menolak ajakan teman sebaya atau kakak kelas mencoba NAPZA yang semula diberikan gratis.

Tabel 2.

Distribusi Frekuensi Warga Binaan Berdasarkan Pendidikan di LPKA PekanbaruTahun 2016 ( $n=25)$

\begin{tabular}{ccc}
\hline $\begin{array}{c}\text { Tingkat } \\
\text { pendidikan }\end{array}$ & $\begin{array}{c}\text { Frekuensi } \\
\text { (orang) }\end{array}$ & $\begin{array}{c}\text { Persentase } \\
(\%)\end{array}$ \\
\hline SD & 7 & 28 \\
\hline SLTP & 13 & 52 \\
\hline SLTA & 4 & 16 \\
\hline D3 / S1 & 1 & 4 \\
\hline Total & $\mathbf{2 5}$ & $\mathbf{1 0 0}$ \\
\hline
\end{tabular}

Berdasarkan tabel 5.3 di atas dapat dilihat bahwa mayoritas responden tingkat pendidikannya adalah SLTP sebanyak 13 orang $(52 \%)$. 
JPK: Jurnal Proteksi Kesehatan

Vol.8, No.2, November 2019, pp. 203 - 213

ISSN 2580-0191 (Online), ISSN 2338 - 5634 (Print)

DOI: $10.29238 /$ teknolabjournal.v\%ix.\%\%\%

\begin{tabular}{|c|c|c|c|}
\hline Hasil penelitian ini sejalan dengan & & abel 3. & \\
\hline penelitian Saprudin & Distribusi Frekuensi & Varga Binaa & 3erdasarkan \\
\hline Sartika (2010) dan & lama menyalahguna & an di LPKAP & anbaruTahun \\
\hline Dwiyanti (2010) yang & & $6(n=25)$ & \\
\hline $\begin{array}{l}\text { penelitian tingkat pendidikannya SMA. } \\
\text { Penelitian Saprudin ( } 2007 \text { dalam Nuraini, }\end{array}$ & $\begin{array}{l}\text { Lama } \\
\text { menyalahgunakan } \\
\text { (tahun) }\end{array}$ & $\begin{array}{l}\text { Frekuensi } \\
\text { (orang) }\end{array}$ & $\begin{array}{l}\text { Persentase } \\
\quad(\%)\end{array}$ \\
\hline 2013) menyatakan 79\% penyalahguna & $1-2$ & 13 & 52 \\
\hline NAPZA adalah siswa SLTA. Penelitian & $3-4$ & 7 & 28 \\
\hline pengaruh & $5-6$ & 4 & 16 \\
\hline kecemasan & $\geq 7$ & 1 & 4 \\
\hline narapidana di Lapas perempuan Semarang & Total & 25 & 100 \\
\hline
\end{tabular}

mengatakan $82,20 \%$ adalah pendidikan rendah (SMP-SMA) yang menyebabkan seseorang mudah mengalami kecemasan. Penelitian Sartika (2010) menjelaskan $82,14 \%$ klien yang menjalani terapi rumatan methadon adalah pendidikan sedang (SMP-SMA).

Hal ini dikarenakan semakin rendah tingkat pendidikan seseorang maka kemampuannya berpikir rasional, menangkap informasi yang baru dan menguraikan masalah semakin rendah pula. Hasil penelitian ini juga sejalan dengan laporan data RSKO yang menunjukkan proporsi terbesar pasien rawat jalan dan inap tahun 2009-2003 adalah latar belakang SMA kemudian diikuti S1 dan D3. Pendidikan merupakan salah satu tolak ukur kemampuan seseorang dalam berinteraksi dengan orang lain secara efektif dan sebagai sumber koping dalam mengatasi masalah (Stuart \& Laraia, 2005) ${ }^{10}$

Jenis pendidikan seseorang berpengaruh dalam memberikan respon terhadap sesuatu yang datang dari luar. Peneliti menganalisis bahwa warga binaan dengan pendidikan SMP lebih banyak dibandingkan dengan pendidikan lain yaitu $S D, S M A$, atau PT, dikarenakan masa SMP merupakan masa menuju kedewasaan seseorang untuk mulai melihat masa depan, dan merupakan masa untuk mencoba halhal baru dengan lingkungan yang lebih luas dan lebih menantang.

Berdasarkan tabel 5.3 di atas dapat dilihat bahwa mayoritas lama mennyalahgukan NAPZA adalah 1-2 tahun sebanyak 13 orang (52\%).

Berdasarkan hasil penelitian diperoleh data bahwa mayoritas lama mennyalahgukan NAPZA adalah 1-2 tahun sebanyak 13 orang $(52 \%)$ dan berdasarkan wawancara mereka rata-rata sudah berobat ke dokter dengan menjalani terapi rawat jalan dan beberapa orang diantaranya sudah mengikuti rehabilitasi.

\section{Analisa Bivariat}

Analisa bivariat digunakan untuk menjelaskan efektifitasThought Stopping (TS)/menghentikan pikiran negatif terhadap proses pikir penyalahgunaan NAPZA Anak yang sedang menjalani pembinaan di Lembaga Pembinaan khusus Anak Kelas II A Pekanbaru pada tabel berikut.

Tabel 4.

Analisis Statistik Efektifitas Thought Stopping

(TS)/Menghentikan Pikiran Negatif Terhadap Proses Pikirdi LPKA PekanbaruTahun $2016(n=25)$

\begin{tabular}{lccc}
\hline Kelompok & $\begin{array}{c}\text { Rata-rata } \\
\pm \mathrm{SD}\end{array}$ & $\begin{array}{c}t \\
\text { hitung }\end{array}$ & $\begin{array}{c}\text { Nilai } \\
\mathrm{P}\end{array}$ \\
\hline Before Tought & $4,64 \pm$ & & \\
Stopping (TS) & 1,4 & 5,53 & 0,000 \\
After Tought & $8,08 \pm$ & & \\
Stopping (TS) & 2,5 & & \\
\hline
\end{tabular}

Analisa bivariat pada penelitian ini didapatkan bahwa + hitung adalah 5,53 dan t tabel pada df 24 pada alfa 0,05 nilainya adalah 2,06 . Bila kita bandingkan antara thitung dan $t$ tabel yaitu t hitung $\geq$ t tabel maka alfha $<0,05$ sehingga dapat 
disimpulkan bahwa terapi Thought Stopping (TS)/menghentikan pikiran negative sangat efektif dalam merubah proses pikir pada warga binaan yang sedang menjalani rehabilitasi di Lembaga Pembinaan Khusus Wanita Kelas II A Pekanbaru.

Analisa bivariat pada penelitian ini didapatkan bahwa $t$ hitung adalah 5,53 dan $t$ tabel pada df 24 pada alfa 0,05 nilainya adalah 2,06 . Bila kita bandingkan antara $t$ hitung dan $t$ tabel yaitu $t$ hitung $\geq$ $t$ tabel maka alfha $<0,05$ sehingga dapat disimpulkan bahwa terapi Thought Stopping (TS)/menghentikan pikiran negatif sangat efektif dalam merubah proses pikir pada warga binaan yang sedang menjalani rehabilitasi di Lembaga Pembinaan Khusus Wanita Kelas II A Pekanbaru.

Berbagai jenis terapi dilakukan sebagai pembelajaran dan praktik secara langsung dalam upaya mengubah pikiran negatif menjadi pikiran positif yang salah satunya adalah Terapi thought stopping. Terapi thought stopping adalah salah satu terapi kognitif perilaku dengan melalui suatu proses menghentikan pikiran yang tinggal dan mengganggu, membantu warga binaan mengatasi pikiran yang mengancam. Terapi thought stopping memerlukan latihan pemutusan pikiran yang pada awal dengan sesuatu yang mengagetkan seperti alarm dan tanda "STOP " dan pada akhirnya dengan suara dan cukup berbisik saja warga binaan sudah dapat menghentikan pikiran negatifnya. Setelah itu warga binaan juga dilatih melakukan thought stopping secara mandiri/otomatis tanpa bantuan terapis mengatakan bahwa terapi prilaku dipandang efektif dalam mengubah proses pikir.

\section{SIMPULAN}

Terapi Thought Stopping (TS)/menghentikan pikiran negative sangat efektif dalam merubah proses pikir pada warga binaan yang sedang menjalani rehabilitasi di Lembaga Pembinaan Khusus Anak Pekanbaru.
UCAPAN TERIMA KASIH

Penulis menyampaikan ucapan terima kasih kepada jajaran manajemen Poltekkes Kemenkes Riau "Kepala Lembaga Pembinaan Khusus Anak Pekanbaru, Reviewer dan Kepala Unit Penelitian dan Pengabdian Masyarakat.

\section{DAFTAR PUSTAKA}

[1] BNN RI.(2009). Advokasi Pencegahan Penyalahgunaan Narkoba. Diambil dari http: kampungbenar.wordpress.com/pemic u-terjadinya-penyalahgunaannarkoba/.Tanggal 10 April 2015

[2] Buletin Data dan Informasi Kesehatan Kemenkes RI, Semester I, Juli 2014

[3] Nursing education, (2008). Consepts of Care in Evidence - Based Practice, Philadelphia : F.A. Davis Company

[4] Sartika, D (2010). Pengaruh Relapse Prevention Training Terhadap Kekambuhan dan Kepatuhan Klien Ketergantungan Heroin yang Menjalani Program Terapi Rumatan Metadon di DKI.Jakarta : FK UI

[5] Diamaluddin (2014). Keluarga dan Penyalahguna Zat Psikoaktif Endemik Sumatera, Padang

[6] Windiarti. (2013), Beberapa Faktor Risiko yang Berhubungan dengan Penyalahguna Narkoba pada Penderita yang Dirawat di Panti Rehabiitasi, Semarang

[7] Windiarti (2014). Hubungan Faktor Individu dan Lingkungan dengan Perilaku Penggunaan NAPZA pada Remaja di Balai Pemulihan Sosial Pamardhi Putra Lembang Bandung, Jakarta : FK UI

[8] Nurdin, A.E (2011).Tumbuh Kembang Perilaku Manusia, Jakarta ; EGC

[9] Sabri, L \& Hastono, S.P. (2010) .Statistik Kesehatan. Jakarta; PT Raja Grafindo Persada.

[10] Stuart \& Laraia (2005). Principles and Practice of Psychiatric Nursing. St. Louis : Mosby 